\title{
Incidence of decreased penicillin sensitivity of Streptococcus pneumoniae from clinical isolates
}

\author{
P NAIR
}

From the Department of Bacteriology, Royal Postgraduate Medical School, Hammersmith Hospital, London

SUMMARY One hundred isolates of Streptococcus pneumoniae isolated from clinical specimens over nine months were examined for sensitivity to penicillin using disc tests and minimum inhibitory concentration (MIC) studies. Four per cent of the isolates were found to have reduced sensitivity to penicillin. Penicillin and methicillin discs with 1 unit and $5 \mu \mathrm{g}$ antibiotic, respectively, were inferior to discs with $1 \mu \mathrm{g}$ oxacillin, which gave results comparable with those of MIC studies.

In a survey in 1965 Streptococcus pneumoniae was found to possess the same degree of sensitivity to penicillin as it did before the introduction of the drug some 50 years ago.' The first report of an isolate of $S$ pneumoniae with a minimum inhibitory concentration (MIC) of $0.6 \mathrm{mg} / \mathrm{l}$ to penicillin came in $1967^{2}$ from Australia, and subsequently resistance to penicillin ${ }^{3}$ and other antibiotics ${ }^{46}$ was reported from many parts of the world. Some such strains showed resistance to multiple antibiotics. ${ }^{7-9}$

In the United Kingdom, however, there have only been sparse reports of relatively resistant $S$ pneumoniae. ${ }^{10}$ Multiple resistant strains reported from this country are probably acquired elsewhere." Although penicillin resistant strains are apparently still very rare here, it would be unreasonable to assume that all strains are highly sensitive. This survey was done to study the sensitivity pattern of $S$ pneumoniae isolated in a teaching hospital and to compare the results of disc tests with oxacillin, methicillin, and low content penicillin to the minimum inhibitory concentrations to penicillin.

\section{Material and methods}

One hundred isolates of $S$ pneumoniae from clinical specimens were collected over nine months (table 1). Alpha-haemolytic streptococci showing characteristic colonial morphology and sensitivity to optochin were identified as $S$ pneumoniae. Subcultures were prepared on blood agar and incubated in oxygen at $37^{\circ} \mathrm{C}$ for 24 hours. Sensitivity tests were carried out on lysed blood agar plates (DST) using the Stokes method. ${ }^{12}$ The Oxford $S$ aureus (NCTC 6571) strain was used as the control. Discs used were penicillin 1 and 2 units, oxacillin 1 and $5 \mu \mathrm{g}$, and methicillin $5 \mu \mathrm{g}$. Muller
Hinton broth with calcium and magnesium supplements (API system) was inoculated with clinical isolates of $S$ pneumoniae and incubated for four hours. The turbidity of the inoculum was that of McFarland's tube No 2. This was then distributed to the cupules in plastic trays commercially prepared by API. The cupules contained penicillin at 11 different concentrations starting with $0.06 \mathrm{mg} / \mathrm{l}$. The twelfth cupule served as a growth control. The strips were then incubated at $37^{\circ} \mathrm{C}$ overnight. The lowest concentration which inhibited bacterial growth was noted and accepted as the minimum inhibitory concentration.

\section{Results}

Ninety six strains had an MIC to penicillin of less than $0.06 \mathrm{mg} / 1$. Two strains had MICs of $0.125 \mathrm{mg} / \mathrm{l}$, one of $0.25 \mathrm{mg} / 1$, and a fourth $0.5 \mathrm{mg} / 1$ (table 1). Strains with

Table 1 Isolation of S pneumoniae from clinical specimens

\begin{tabular}{|c|c|c|c|c|}
\hline $\begin{array}{l}\text { Site of } \\
\text { specimen }\end{array}$ & $\begin{array}{l}\text { No of } \\
\text { specimens }\end{array}$ & $\begin{array}{l}\text { No of } \\
\text { patients }\end{array}$ & $\begin{array}{l}\text { Other } \\
\text { pathogens }\end{array}$ & $\begin{array}{l}\text { MIC of } \\
\text { moderately } \\
\text { resistant strains }\end{array}$ \\
\hline Eye & 10 & 10 & \multicolumn{2}{|l|}{$\begin{array}{l}1 \text { patient with } \\
H \text { influenzae }\end{array}$} \\
\hline CSF (without & $\begin{array}{l}2 \\
6\end{array}$ & $\begin{array}{l}2 \\
6\end{array}$ & & \\
\hline $\begin{array}{l}\text { Blood } \\
\text { Wound }\end{array}$ & $\begin{array}{l}0 \\
4\end{array}$ & $\begin{array}{l}0 \\
4\end{array}$ & \multicolumn{2}{|l|}{$\begin{array}{l}1 \text { patient with } \\
S \text { aureus }\end{array}$} \\
\hline Genital tract & 1 & 1 & & \\
\hline Pleural aspirate & $\begin{array}{l}2 \\
\text { (1 month } \\
\text { apart) }\end{array}$ & 1 & \multirow[t]{3}{*}{$\begin{array}{l}\text { Anaerobes in } \\
\text { second } \\
\text { specimen }\end{array}$} & \\
\hline Nose & 6 & 6 & & \multirow{2}{*}{$\begin{array}{l}0.125 \mathrm{mg} / \mathrm{l} \text { (1 } \\
\text { strain) } \\
0.5 \mathrm{mg} / \mathrm{l} \text { (1 strai } \\
0.125 \mathrm{mg} / \mathrm{l}(1 \\
\text { strain) } \\
0.25 \mathrm{mg} / \mathrm{l} \text { (1 } \\
\text { strain) }\end{array}$} \\
\hline $\begin{array}{l}\text { Throat } \\
\text { Sputum }\end{array}$ & $\begin{array}{r}1 \\
68\end{array}$ & $\begin{array}{r}1 \\
68\end{array}$ & & \\
\hline
\end{tabular}


Table 2 Association between zone sizes* (mm) and MIC $(m g / l)$

Oxacillin 1 Oxacillin 5 Penicillin 1 Penicillin 2 Methicillin 5

\begin{tabular}{|c|c|c|c|c|}
\hline \multicolumn{5}{|l|}{$\begin{array}{l}\text { Strain } 1 \\
\text { MIC 0.12513 (17) }\end{array}$} \\
\hline MIC 0.12511 (11) & $14(14)$ & $13(13)$ & $15(15)$ & $15(15)$ \\
\hline MIC 0.25 $0(16)$ & $11(17)$ & $14(14)$ & $16(16)$ & $15(15)$ \\
\hline MIC 0.5 $11(16)$ & $11(16)$ & $10(13)$ & $14(14)$ & $15(16)$ \\
\hline
\end{tabular}

Oxacillin $1=$ mean $(\mathrm{SD}) 18(2 \cdot 4)$

Penicillin $1=$ mean (SD) $19(1.9)$

Methicillin $5=$ mean (SD) $19(1.4)$

*Zone sizes of controls in parentheses

a penicillin MIC of less than $0.06 \mathrm{mg} / \mathrm{l}$ had zones larger than the control in all cases when tested with a disc containing 2 units penicillin or $5 \mu \mathrm{g}$ oxacillin. For the same strains $5 \mu \mathrm{g}$ methicillin disc zone sizes were 17-21 mm (mean (SD) 19 (1.4) mm) compared with the control which was $17-20 \mathrm{~mm}$. When tested with a 1 unit penicillin disc, zone diameter varied from 17-22 mm 19 (1.9) compared with the control zone of 11-20 mm. An oxacillin 1 unit disc gave zone sizes of 16-20 mm $18(2 \cdot 4)$.

Three of the four strains with an increased MIC to penicillin had a reduced zone on testing with $1 \mu \mathrm{g}$ discs of oxacillin compared with the control (table 2). Penicillin 2 units, oxacillin $5 \mu \mathrm{g}$, and methicillin $5 \mu \mathrm{g}$ discs did not show differences in zone sizes between any of these four strains and the control. None of the strains was fully resistant - that is, with an MIC of 1 $\mathrm{mg} / \mathrm{l}$ or more. Three of the strains were from patients who had not travelled abroad while the fourth strain was from a Sudanese student temporarily resident in this country.

\section{Discussion}

This survey has shown that some strains of pneumococci in the United Kingdom exhibit decreased sensitivity to penicillin. North American workers divide $S$ pneumoniae into three groups according to its sensitivity pattern. ${ }^{13}$ Fully resistant strains are those with an MIC of $>\mathrm{mg} / \mathrm{l}$; the fully sensitive strains have MICs of $<0.1 \mathrm{mg} / \mathrm{l}$. Those falling between these two limits are designated as moderately resistant. These moderately resistant strains may have therapeutic importance. ${ }^{14} 15$

The National Committee for Clinical Laboratory Standards (USA) ${ }^{16}$ recommends the use of discs containing $1 \mu \mathrm{g}$ oxacillin to differentiate between susceptible and resistant strains. In our study all strains with reduced sensitivity to penicillin had smaller zones than the control with $1 \mu \mathrm{g}$ oxacillin (table 2). At least one of these strains, however, would have been labelled sensitive if the Stokes method alone was used for sensitivity testing.

While the need to differentiate between moderately resistant and resistant strains may be debatable, it is important to recognise any pattern of reduced susceptibility for therapeutic and epidemiological purposes. ${ }^{14-18}$ It is no longer justifiable to assume that all $S$ pneumoniae are sensitive to penicillin. This survey showed that $1 \mu \mathrm{g}$ oxacillin discs were superior in identifying strains less sensitive to penicillin. These results are comparable with those of MIC studies. Therefore, while doubt exists as to the usefulness of penicillin and methicillin discs, ${ }^{16-20}$ we recommend the use of oxacillin $1 \mu \mathrm{g}$ discs for screening purposes, and MIC studies to confirm the results.

References

1 Kislak JW, Razavi LMB, Daly AK, Finland M. Susceptibility of pneumococci to nine antibiotics. Am J Med Sci 1965;250:261-8.

2 Hansman D, Bullen MM. A resistant pneumococcus. Lancet 1967;ii:264-5.

3 Anonymous. Penicillin-resistant pneumonocci. [Editorial]. $\mathrm{Br}$ Med J 1971;ii:667.

4 Evans L, Hansman D. Tetracycline resistant pneumococcus. Lancet 1963;i:451.

5 Kislak JW. Type 6 pneumococcus resistant to erythromycin and lincomycin. N Engl J Med 1967;276:852.

6 Hansman D. Chloramphenicol resistant pneumococci in West Africa. Lancet 1978;i:1102.

7 Applebaum PC, Bhamjee A, Scragg JN, et al. Streptococcus pneumoniae resistant to penicillin and chloramphenicol. Lancet 1977;ii:995-7.

8 Ward J, Koornhof H. Antibiotic resistant pneumococci. In: Remington JS, Swarts MN, eds. Current clinical topics in infectious diseases. Vol 1. New York: McGraw-Hill, 1980: 265-87.

9 Applebaum PC. Worldwide development of antibiotic resistance in pneumococci. Eur J Clin Microbiol 1987;6:367-77.

10 Howard AJ, Hince CJ, Williams JD. Antibiotic resistance in Streptococcus pneumoniae and Haemophilus influenzae. $\mathrm{Br}$ Med J 1978;i:1657-60.

11 Paton JH, Reeves DS. First multiresistant pneumococcus in Britain. Br Med J 1987;295:810-1.

12 Stokes EJ, Ridgway G. Clinical bacteriology. 5th Edn. London: Edward Arnold, 1980.

13 Jacobs MR, Gaspar MN, Robins-Browne RM, Koornhof HJ. Antimicrobial susceptibility testing of pneumococci. 2. Determination of optimal disc diffusion test for detection of penicillin G resistance. J Antimicrob Chemother 1980;6:53-64.

14 Howes VJ, Mitchell RG. Meningitis due to a relatively penicillin resistant pneumococci. Br Med J 1976;i:996.

15 Pallares R, Gudiol F, Linares J, et al. Risk factors and response to antibiotic therapy in adults with bacteraemic pneumonia caused by penicillin-resistant pneumococci. $N$ Engl J Med 1987;317: 18-22.

16 Edson DC, The CAP Microbiology Resource Committee. The ability of participant laboratories to detect penicillin resistant pneumococci. Am J Clin Pathol 1982;78 (suppl):659-63.

17 Klugman KP, Koornhof HJ, Wasas A, Storey K, Gilbertson I. Carriage of penicillin resistant pneumococci. Arch Dis Child 1986;61:377-8.

18 Thorburn JR, Koornhof HJ. Community-acquired pneumonia due to penicillin in resistant pneumococci. $N$ Engl $J$ Med 1985;313:615-7.

19 Swenson JM, Hill BC, Thornsberry C. Screening pneumococci for penicillin resistance. J Clin Microbiol 1986;24:749-52

20 Rees T, Waterworth PM. A problem with the recognition of penicillin resistant pneumococci. J Clin Pathol 1980;33:1092-4.

Requests for reprints to: Dr $P$ Nair, Department of Microbiology, Edgware General Hospital, Edgware, Middlesex, England. 